Likewise, liaison between organisations at government and national levels is a prerequisite for deciding policies and disseminating information clearly and quickly. Local collaboration also has an important role in discussing local and national issues. Meetings are currently mostly confined to regular and ad hoc meetings between professionals from organisations such as the state veterinary service, health protection agencies, and local and water authorities. ${ }^{10}$ Little routine local collaboration occurs between the medical and veterinary professions in general practice.

But sharing local knowledge and expertise would have real benefits for the immediate human and animal populations. Sporadic or community and animal outbreaks of salmonellosis may, for example, have a common source of which only one profession is aware. Other potential benefits include reduced incidence of antibiotic resistance through sharing and comparing use, highlighting common environmental hazards such as farm discharges, and identifying research priorities.

The time has surely come for medical and veterinary general practitioners to get together to share knowledge and voice concerns. Local concerns, which may become national problems, can be identified only through an open and integrated professional approach. Willingness by both the veterinary and medical professions at both local and national levels to collaborate and share information is therefore essential for the protection and promotion of public health.

Cameron Stewart specialist in veterinary public health

(cameron.stewart@svs.gsi.gov.uk)

John Cowden consultant in health protection

Jim McMenamin consultant in health protection

Bill Reilly consultant in veterinary public health

Health Protection Scotland, Glasgow G3 7LN

Competing interests: None declared.

1 World Health Organization Study Group. Future trends in veterinary public health. World Health Organ Tech Rep Ser 2002;907:1-85. http:// whqlibdoc.who.int/trs/WHO TRS 907.pdf (accessed 9 Nov 2005).

2 Schwabe CW. Cattle, priests, and progress in medicine. Minnesota: University Schwabe CW. Cattle, priests,
of Minnesota Press, 1978.

3 European College of Veterinary Public Health. www.vu-wien.ac.at/ ausland/ECVPH.htm (accessed 9 Nov 2005).

4 Taylor LH, Latham SM, Woolhouse MEJ. Risk factors for human disease emergence. Philos Trans R Soc Lond B 2001;356:983-9.

5 Meslin FX, Stohr K, Heymann D. Public health implications of emerging zoonoses. Rev Sci Tech 2000;19:310-7.

6 World Health Organization. Epidemic and pandemic alert response. www.who.int/csr/en/ (accessed 9 Nov 2005).

7 McGuigan CC, Penrice GM, Gruer L, Ahmed S, Goldberg D, Black M, et al. Lethal outbreak of infection with Clostridium novyi type A in Scottish al. Lethal outbreak of infection with Clostric
drug users. J Med Microbiol 2002;51:971-7.

8 Scottish Executive Health Department, Food Standards Agency (Scotland). Report of the E coli O157 task force. Edinburgh: Stationery Office, 2001. www.food.gov.uk/news/newsarchive/2001/oct/ecolitask (accessed 9 Nov 2005).

9 Bräunig J, Hensel A. Risk assessment of foodborne infections. Dtsch Tierärztl Wochenschr 2004;111:304-7.

10 Scottish Centre for Infection and Environmental Health. Guidelines for the investigation of zoonotic disease in Scotland. www.show.scot.nhs.uk/scieh/ PDF/Updated_Guidelines_Zoonoses_Oct03.pdf (accessed 9 Nov 2005).

\title{
A walk on the wild side-emerging wildlife diseases
}

\section{They increasingly threaten human and animal health}

$\mathrm{E}$ merging infectious diseases have been creeping up the research agenda since at least 1992, when the US Institute of Medicine defined them as infectious diseases that have recently increased in incidence or geographical range, recently been discovered, or are caused by newly evolved pathogens. ${ }^{1}$ Diseases that have recently moved into new species can be added to this defining list. ${ }^{2}$ More recently, the emergence of diseases with high case fatality rates-such as AIDS, severe acute respiratory syndrome (SARS) and H5N1 avian influenza-have catapulted emerging infectious diseases to the top of the medical and political agendas, simultaneously highlighting the importance of wildlife as reservoirs or vectors for disease.

A topical example is avian influenza, which can cause human pandemics after genetic mutation or reassortment between influenza viruses of wild and domestic birds, other animals, and humans. The prospect of a global pandemic of $\mathrm{H} 5 \mathrm{~N} 1$ is very real, at least for wild birds and mammals, and possibly also for humans. Another example is HIV infection and AIDS, which emerged from at least two non-human primate reservoirs in Africa. ${ }^{3}$ Fruit bats have been implicated as reservoirs of several high profile viral zoonoses that have emerged over the past decade, including SARS. ${ }^{4}$ For some pathogens, secondary "amplifier" hosts are required for transmission to humans: thus, Hendra virus emerged from fruit bats to horses and then to humans in Australia in 1994-5, and Nipah virus emerged from fruit bats to pigs and dogs to humans in Malaysia in 1998-9. ${ }^{2}$ Nipah virus has since emerged in Bangladesh, where the virus is genetically distinct from that in South East Asia, ${ }^{5}$ and human to human transmission possibly occurs. ${ }^{6}$ Nipah virus should be kept on the "radar screen" for potential human pandemics: in the 1998-9 outbreak 106 people died in the absence of transmission between humans.

Of the 1415 known human pathogens, $61 \%$ are zoonotic. ${ }^{7}$ Of pathogens causing emerging infectious diseases, however, $75 \%$ are zoonotic, with wildlife being an increasingly important source. ${ }^{2}$ This is not surprising, as non-zoonoses will likely already be endemic while zoonoses from domesticated species probably emerged over millenniums of close association with humans. Indeed, some established human diseases, such as measles, probably originated from these animals around the time of domestication. ${ }^{8}$ Wildlife, however, continue to be a reservoir of unfamiliar microorganisms from which previously unknown pathogens continue to emerge. It is estimated that only about a fifth to a 50th of species have been documented, ${ }^{9}$ so the reservoir of potential zoonotic pathogens is vast. But why are we now seeing an appar-
See Papers, p 1242 Education and Debate, p 1256-60

(a) 


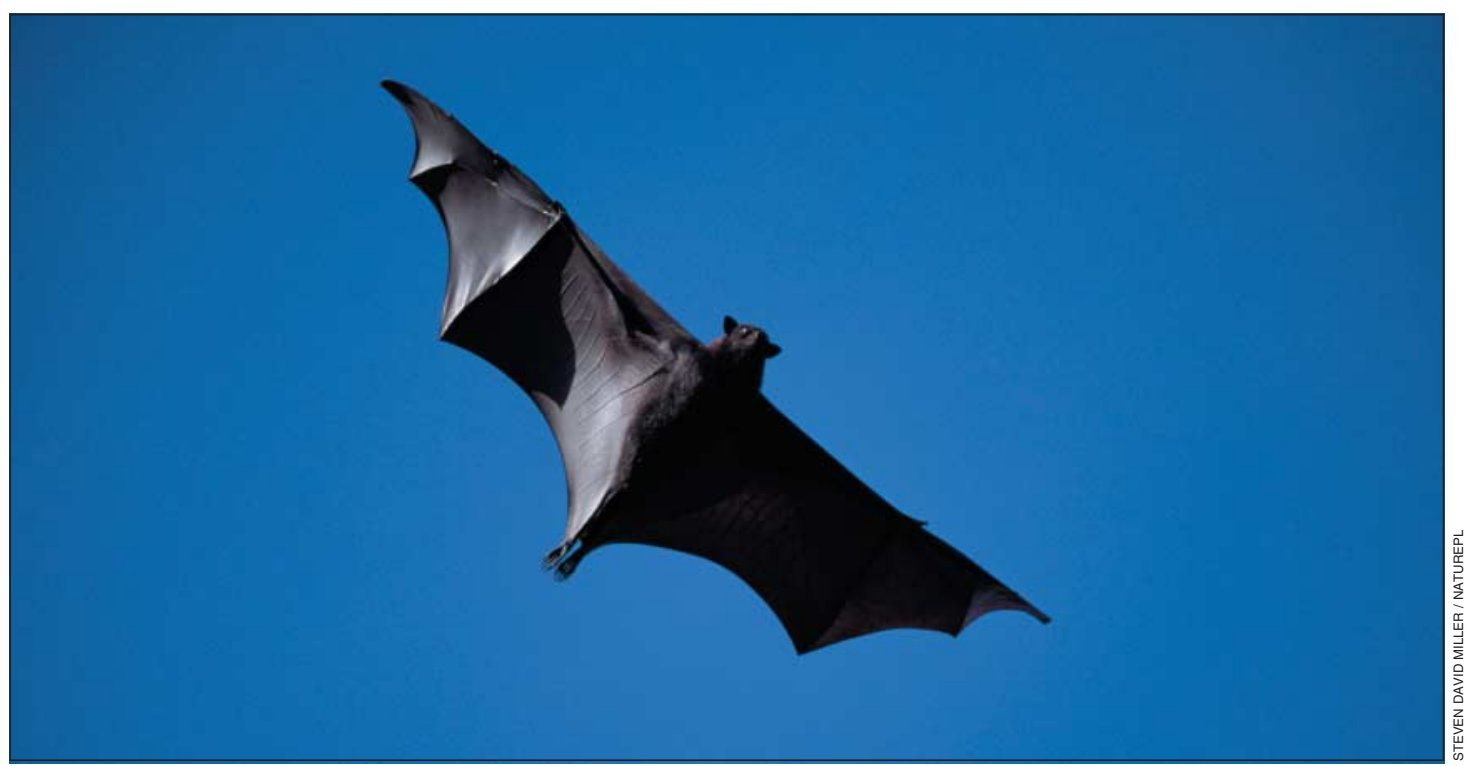

Pteropus alecto - the black flying fox-known to carry Hendra virus

ently rapid increase in the emergence of new zoonoses from wildlife?

One of the major drivers of the emergence of infectious disease is closer human contact with wildlife, primarily caused by human encroachment into, and modification of, wildlife habitat. As the human population continues to grow, our needs for space and resources result in further encroachment into a diminishing natural world. For example, Nipah virus spilled over from fruit bats when forest was cleared for pig farming; Ebola virus outbreaks often are linked to hunting for "bushmeat" or to mining development; and the AIDS pandemic originated from human encroachment into African forests for food.

New zoonoses have probably emerged many times from wildlife historically but failed to spread from the focus of emergence: infected people either died or recovered before contacting larger human populations. In modern times, however, the exponential rise in volume and speed of trade and travel has transformed the epidemiology of emerging infectious diseases, giving the outcomes of emergence events global rather than local importance. The international trade in wildlife is now huge, with hundreds of millions of wild animals and their products being traded globally each year. ${ }^{10}$ Also, travellers can be in the middle of a tropical jungle one day and commuting to their desk in London the next. The emergence of West Nile virus in North America, and AIDS and SARS globally, for example, arose from such travel and trade. This globalisation of people and products is difficult to control and is largely related to increasing air transportation. With world air travel expected to grow at about $5 \%$ a year for at least the next 20 years, ${ }^{11}$ the problem of emerging infectious diseases will continue to grow.

Emerging infectious diseases are not only a problem for human health but are a major threat to animal welfare and to species conservation. ${ }^{212}$ The same principles for disease emergence in humans apply to wildlife. A study of the drivers of disease emergence in wildlife showed that human movement of pathogens by trade and travel is the most important. ${ }^{12}$ The emergence and spread of new wildlife diseases increases the potential for disease emergence in humans, as has occurred with the spread of West Nile virus to, and within, the Americas. ${ }^{12}$ Some emerging infectious diseases also threaten domesticated species, such as the threat West Nile virus poses to the US racehorse industry and the slaughter of 1.1 million pigs to control emergence of Nipah virus in Malaysia. Through emerging infectious diseases, therefore, the medical, veterinary, and wildlife conservation professions share a common agenda. The problem is not small, and tackling it will not be easy, but recognising a common problem is, at least, a start.

Andrew A Cunningham reader in wildlife epidemiology

Institute of Zoology, Zoological Society of London, London NW1 4RY (a.cunningham@ioz.ac.uk)

Competing interests: None declared.

1 Lederberg J, Shope RE, Oakes SC Jr. Emerging infections: microbial threats to health in the United States. Washington, DC: Institute of Medicine, National Academy Press, 1992.

2 Daszak P, Cunningham AA, Hyatt AD. Emerging infectious diseases of wildlife-threats to biodiversity and human health. Science 2000;287. wildiife.

3 Hahn BH, Shaw GM, De Cock KM, Sharp PM. AIDS-AIDS as a zoonosis: scientific and public health implications. Science 2000;287:607-14.

$4 \mathrm{Li}$ W, Shi Z, Yu M, Ren W, Smith C, Epstein JH, et al. Bats are natural reservoirs of SARS-like coronaviruses. Science 2005;310:676-9

5 Harcourt BH, Lowe L, Tamin A, Liu X, Bankamp B, Bowden N, et al. Genetic characterization of Nipah virus, Bangladesh, 2004. Emerg Infect Dis 2005;11:1594-7.

6 Hsu VP, Hossain MJ, Parashar UD, Ali MM, Ksiazek TG, Kuzmin I, et al. Nipah virus encephalitis reemergence, Bangladesh. Emerg Infect Dis 2004:10:2082-7.

7 Taylor LH, Latham SM, Woolhouse ME. Risk factors for human disease emergence. Philos Trans R Soc Lond B Biol Sci 2001:356:983-9.

8 Dobson AP, Carper ER. Infectious diseases and human population history Bioscience 1996:46:115-26.

9 Brackett D, Medellin RA, Caceres C, Mainka S. Biodiversity and human livelihoods-the state of the planet in 2004. Commissioned issue paper of the United Nations Millennium Project Task Force on Environmental Sustainability, 2004. www.unmillenniumproject.org/documents/TF6\%20 IP1\%20Biodiversity.pdf (accessed 6 Oct 2005).

10 Karesh WB, Cook RA, Bennett EL, Newcomb J. Wildlife trade and global disease emergence. Emerg Infect Dis 2005;11:1000-2.

11 Daszak P, Cunningham AA. Anthropogenic change, biodiversity loss and a new agenda for emerging diseases. J Parasitol. 2003;89:S37-41.

12 Cunningham AA, Daszak P, Rodríguez JP. Pathogen pollution: defining a parasitological threat to biodiversity conservation. J Parasitol 2003;89: parasitologi 